\title{
Correction to: Olfactory discrimination of anal sac secretions in the domestic cat and the chemical profiles of the volatile compounds
}

\author{
Tamako Miyazaki $^{1} \cdot$ Takashi Nishimura $^{1} \cdot$ Tetsuro Yamashita $^{1} \cdot$ Masao Miyazaki ${ }^{1}$ (I)
}

Published online: 31 December 2018

(c) The Author(s) 2018

\section{Correction to: Journal of Ethology (2018) 36:99-105 https://doi.org/10.1007/s10164-017-0532-x}

The article Olfactory discrimination of anal sac secretions in the domestic cat and the chemical profiles of the volatile compounds, written by Tamako Miyazaki, Takashi Nishimura, Tetsuro Yamashita and Masao Miyazaki was originally published electronically on the publisher's internet portal (currently SpringerLink) on 16 November, 2017 without open access. With the author(s)' decision to opt for Open Choice the copyright of the article changed on 18 December, 2018 to () The Author(s) 2018 and the article is forthwith distributed under the terms of the Creative Commons Attribution 4.0 International License (http://creativecommons .org/licenses/by/4.0/), which permits use, duplication, adaptation, distribution and reproduction in any medium or format, as long as you give appropriate credit to the original author(s) and the source, provide a link to the Creative Commons license and indicate if changes were made.

The original article has been corrected.

Open Access This article is distributed under the terms of the Creative Commons Attribution 4.0 International License (http://creativecommons.org/licenses/by/4.0/), which permits unrestricted use, distribution, and reproduction in any medium, provided you give appropriate credit to the original author(s) and the source, provide a link to the Creative Commons license, and indicate if changes were made.
The original article can be found online at https://doi.org/10.1007/ s10164-017-0532-x.

Masao Miyazaki

mmasao@iwate-u.ac.jp

1

\footnotetext{
Department of Biological Chemistry and Food Sciences,

Faculty of Agriculture, Iwate University, 3-18-8 Ueda,

Morioka, Iwate 020-8550, Japan
} 